\title{
Building bridges across subdisciplines in marine ecology*
}

\author{
LAWRENCE R. POMEROY \\ Institute of Ecology, University of Georgia, Athens GA 30602-2202, USA. E-mail: 1pomeroy@ecology uga.edu
}

\begin{abstract}
SUMMARY: Ecology has evolved many subdisciplines whose members do not necessarily communicate regularly through attending the same meetings or reading and publishing in the same journals. As a result, explanations of ecological processes are often limited to a single factor, process, or group of organisms, and this limited approach may fail to provide the best understanding of how communities and ecosystems are assembled and function. Specifically, there is a need to bring together information on the interplay of top-down and bottom-up influences on complete communities consisting of both macroorganisms and microorganisms. A number of examples from the recent literature illustrate the problems encountered in achieving this goal. These include declining fish populations, estuarine eutrophication, the complex origin of a toxic dinoflagellate bloom, and the interactions of microorganisms and macrooorganisms in marine planktonic food webs.
\end{abstract}

Key words: bridging subdisciplines, top-down, bottom-up, eutrophication, overfishing, dinoflagellate blooms.

RESUMEN: TENDER PUENTES ENTRE SUBDISCIPLINAS EN ECOLOGíA MARINA. - La ecología ha dado lugar a muchas subdisciplinas cuyos miembros no se comunican necesariamente de manera regular, pues no asisten a las mismas reuniones ni leen o publican en las mismas revistas. El resultado es que las explicaciones de los procesos ecológicos se suelen limitar a un único factor, proceso o grupo de organismos, y este enfoque limitado puede no proporcionar la mejor manera de comprender cómo están ensamblados y funcionan las comunidades y los ecosistemas. Más en concreto, es necesario aunar información sobre la interacción del control desde arriba y del control desde abajo sobre comunidades completas constituidas tanto por macroorganismos como por microorganismos. Varios ejemplos de la bibliografía reciente ilustran los problemas que se plantean a la hora de conseguir este objetivo. Entre ellos están la reducción en las poblaciones de peces, la eutrofización estuárica, el complejo origen de una proliferación de dinoflagelados tóxicos y las interacciones entre microorganismos y macroorganismos en las redes tróficas planctónicas marinas.

Palabras clave: puentes entre subdisciplinas, control desde arriba, control desde abajo, eutrofización, sobrepesca, proliferaciones de dinoflagelados.

\section{INTRODUCTION}

To describe or understand the structure and function of entire communities and ecosystems through the examination of one factor, process, or group of organisms seems obviously futile. The tendency of investigators to focus on one attribute of a community may lead us astray and delay better understand-

*Received November 2, 2001. Accepted November 19, 2002. ing. Yet, much of the current literature continues to focus on few or single attributes of communities. Specifically, two common dichotomies of ecology need integration. The traditional emphasis on control of communities through bottom-up processes of environmental limitations such as light, nutrients, and other resources has in recent years given way to an emphasis on top-down regulation of community structure and function through predator control of grazers and/or grazer control of primary producers. 
Some investigators have for a long time advocated that both top-down and bottom-up controls are significant, acting concurrently and perhaps synergistically, but the message seems to need reinforcement (Bjørnstad and Grenfell, 2001).

Another traditional emphasis in ecology has been on the interactions of macroorganisms while relegating microbial ecology to a black box labeled "detritus" or "decomposers". The science of microbial ecology is largely of recent origin and tends to remain a separate study that is not always seen as having much relevance to the organization and function of communities of macroorganisms. While in some situations this may be true, the recent literature shows that microbial processes can sometimes be dominant ones, notably in marine plankton. Thus, understanding the organization and function of a natural community ought to combine knowledge of both top-down and bottom-up influences on the entire spectrum of organisms from bacteria to whales. A number of recent studies make a beginning at doing that, while some others show evidence of having needed to do it.

\section{TOP-DOWN VERSUS BOTTOM-UP INFLUENCES}

A number of recent studies are filling gaps in our knowledge of both top-down and bottom-up influences on the organization of communities. Lotze et al. (2001) found that both nutrient supply and grazing pressure influenced the development of communities of macroalgae. In various environments one or the other might be the more influential, making it difficult to predict outcomes. The development of marine zooplankton populations has traditionally been related to phytoplankton production and food supply. However, Ohman and Hirche (2001) present evidence that egg predation and egg cannibalism have very significant top-down influence on the development of populations of marine copepods. Their observation does not, of course, negate the influence of food supply; one must consider both nutrition and population interactions. Like many cascades, these are at the level of species or trophic groups rather than whole communities, which makes them more difficult to tease out from community processes but no less important. In the following examples, the relative influences of topdown and bottom-up processes are still being debated in the literature.

\section{Crashing cod fisheries}

Cod stocks, as well as many fish populations suffering from overfishing, have crashed during the last decade, especially in the northwest Atlantic. The decline of spawning biomass to little more than $1 \%$ of historic levels and the harvest of progressively smaller, immature fish is well documented (Meyers et al., 1996). Reduction of fishing pressure is a necessary, but not sufficient, step toward replenishing the stocks. Regrettably, as Hutchings (1996) suggests, even the obvious step of ceasing fishing for more than a decade is not a politically viable prospect. It would seem that this sort of pressure also affects science in subtle ways. As if to make the strongest case for removing fishing pressure, Hutchings (1996) essentially rejects all other factors as trivial. Specifically, he rejects the possibility of temperature effects while assuming that warmer is better. However, Meyers et al. (2001) present a model that suggests a negative relation between water temperature and carrying capacity in North Atlantic cod, making present temperature trends something to consider.

Cod populations in the Baltic, while reduced from historic norms, have fared better than those of the North Atlantic, perhaps because of more successful management by ICES. However, Kornilovs et al. (2001) postulate that the observed decline has had, at least in part, an environmental basis in reduced food supply (Calanus). In contrast, Fromentin et al. (1998) examine the historic record in the Skagerrak and suggest no relation of cod populations to Calanus, whose abundance cycles with the North Atlantic oscillation. Rather, Fromentin et al. (1998) relate changes in cod stocks to changes in amount of area of Zostera available for settlement of the larvae -in other words, a space limitation for juveniles. While no simple answer seems to be in sight, the potential influence of environmental variables cannot be discounted. Several recent studies have documented a correlation between environmental cycles and the biomass of fish populations. For example, the Pacific Decadal Oscillation, a multi-decade weather pattern that has gone through three changes in the past century, correlates with productivity of most Pacific salmon species, presumably through influences of water temperature and wind fields on food supply (Hare et al., 1999). A correlation also has been found between halibut production in the Gulf of Alaska and a long-term tidal regime (Royer et al., 2001). Telecommunica- 
tions between distant populations, such as the 300year correlations between the abundance of Bohlusän herring off Sweden and anchovies in the California current, also suggest the influence of weather cycles (Schwartslose et al., 1999).

Laid over these low-frequency regional weather oscillations, which may account for $\geq 50 \%$ of the population variance, are high-frequency oscillations arising from short-term environmental variability, population interactions, and demographic stochasticity (Bjørnstad and Grenfell, 2001). This combination of non-linear variables, acting over a range of scales of space and time, remains a challenge to our ability to develop better data, better models, and better statistical analyses. The practical success of such endeavors is further challenged by political realities. Fisheries are a good example of a political problem that cries out for a simple solution and to which scientists sometimes respond by seeking one. Kendall (1999) says, "One can now easily discern a "conservation wing' and a 'science wing' [of the American Fisheries Society] and a thinning middle rank of uneasy professionals trying to balance a need to act with a need to know." A guarantee that a fishing moratorium alone will result in the return of stocks to previous levels is not assured, and in any case the return time may be measured in decades. Science and politics often create a poor mixture. Politicians want results before the next election. Scientists need to educate both politicians and the public about the limits and realities of basic science and scientific management. Science is not magic.

A classic example of naturally occurring oscillations in fish populations is the oscillation between anchovy and sardine dominance (Schwartslose et al., 1999). Decade-scale oscillations between dominance of anchovy and sardine are known from pre-historic sediment records as well as from fishery statistics. So, while we know these regime shifts occur naturally, recent ones have been attributed to overfishing, and that would appear to be in part correct. Jacobson et al. (2001) calculate that the annual surplus production (ASP), which can be harvested without detriment to reproduction, averages only $16 \%$ of the stock, and is correlated with stock size. Thus, low stocks are most sensitive to fishing pressure, and years of negative ASP are not unusual. However, Jacobson et al. (2001) state that while fishing pressure can have negative shortterm effects on these fisheries, environmental effects dominate long-term trends in reproductive success. While such conclusions can be reached from hindsight, the complexities of the environmental effects are such that forecasting is elusive. Both Jacobson et al. (2001) and Schwartslose et al. (1999) suggest that better management of these important fisheries should be based on ASP, as determined from the most recent year classes and not from statistics of fish landings, which tend to be insensitive to changes in fish stocks. Even with this refinement, environmental effects, such as changes in ENSO and NAO weather regimes, can be expected to have effects on regime shifts and fish abundance. Defining alternate attractors requires understanding not just weather but proximate causes, which may include many factors, top-down and bottom-up. Within the science wing of fisheries management a move has developed to understand not just fish populations but the large marine ecosystems in which marine fish populations live (Sherman and Duda, 1999).

\section{Eutrophic Chesapeake Bay}

The effects of keystone species can sometimes be documented by experiments such as those pioneered by Paine (1980), but some proposed examples are problematic. One that has become a science legend among environmentalists is the proposed role of oysters in enhancing the anoxic zone of Chesapeake Bay (e. g. Jackson et al., 2001). The reasoning originally proposed by Newell (as reported by Jonas, 1997), is that the large decrease in the oyster population resulting from overfishing caused the documented increase in phytoplankton, which is then said to have caused increased release of dissolved organic material (DOM) by phytoplankton, in turn increasing the biomass of heterotrophic bacteria, which cause anoxia. It must be noted that this latter part is pure supposition, since there are no long-term historical data on bacterial abundance, production, or respiratory rate. Further, the logic seems questionable. Production of DOM by phytoplankton is a function of phytoplankton production, not abundance. Increased standing stock does not imply increased production but the reverse. Heavily grazed populations of phytoplankton are expected to be more productive of new biomass and thus more DOM. However, recent research suggests that the direct utilization of DOM release by phytoplankton is a less significant source of substrates for bacteria than secondary sources such as excretion and fecal products of protozoans and zooplankton (Nagata, 2000). 
Most reviews of this subject suggest that the increasing extent of anoxia in Chesapeake Bay, as is also happening in the Gulf of Mexico (Turner and Rabalais, 1994) and elsewhere results from eutrophication, a bottom-up influence, and not from a reduction in oyster populations. The observed increase in phytoplankton standing stocks in Chesapeake Bay may result in part from reduced filtration of the water by oysters, but the rates of phytoplankton production suggest a response to the 6-8 fold increase in nitrogen inputs since pre-colonial time (Boynton et al., 1995). Similar increases in nitrogen have occurred in other estuaries and coastal waters (Nixon, 1995), sometimes with similar results (Turner and Rabalais, 1994). Jackson et al. (2001) state that the microbial loop has increased in Chesapeake Bay, although they offer no supporting data. However, the standing stocks of bacteria in Chesapeake Bay are comparable to those in other estuaries and river plumes (e. g. Chin-Leo and Benner, 1992), but microbial respiratory rates are high (Sampou and Kemp, 1994), suggesting eutrophication.

Anthropogenic changes in estuarine and coastal ecosystems over the past 500 years have included the reduction of populations of many large vertebrates and some invertebrates (Jackson et al., 2001) and also increased inputs of nitrogen and phosphorus (Nixon, 1995). Loss of vertebrate populations high in the food chain has resulted in cascades up and down those food chains (Sherman and Duda, 1999). At the same time, saturation of these environments with nutrients has increased primary production (Boynton et al., 1995). While unexploited invertebrates and some vertebrate species have undoubtedly increased to fill vacant niches, such as filter-feeding, bacteria probably have increased relatively little in numbers or biomass but have increased their metabolism and production rates (Pomeroy, 2001). This latter postulate must be based on observations of current research, since there are no historical data. We should also remember that anoxia in estuaries and shallow coastal waters is a natural phenomenon, well known in the geological record (Tyson and Pearson, 1991), and is a characteristic of productive coastal ecosystems (Pomeroy et al., 2000). The concern is not to eliminate anoxia but to prevent an excess that may be deleterious to fisheries or other interests.

\section{Oceanic bacterioplankton populations}

A remarkable and now quite well documented case of strong controls from both top-down and bottom-up influences is that of the bacterioplankton in the ocean. In the upper waters of the ocean, away from the continental shelves, the numbers of bacteria are within an order of magnitude of $10^{8} 1^{-1}$ throughout the world's ocean, from the tropics to polar seas (Ducklow, 2000). This remarkably small range of abundance for organisms with such a large growth potential results from the combined controls of nutrition and predation. Experimentally, it is known that most of the time in most of the ocean, bacterial production is limited by the supply of organic substrates or inorganic nutrients, N, P, Fe, or some combination of several of these. However, in situations where nutrition is not limiting, flagellate grazers limit population growth. Concentrations of bacterioplankton below $10^{8} 1^{-1}$, appear to be a refuge of scarcity; it is difficult for the flagellates to find the last bacterium. At concentrations much above $10^{8}$ $1^{-1}$, flagellates readily find the bacteria and, with a growth potential near that of the bacteria, quickly reduce them to their refuge concentration. Hall and Safi (2001) have demonstrated this in the field during an iron fertilization experiment in the Southern Ocean. Following Fe addition, the rate of bacterioplankton production increased by a factor of 3 , and flagellate abundance increased, but the numbers of bacterioplankton did not change significantly.

\section{The importance of multiple factors}

Although sweeping arguments against the significance of bottom-up influence have persisted from those of Paine (1980) to Verity (1998), a few factors would seem to explain a good deal. Margalef et al. (1979) showed that the interaction of turbulence, nutrients, and $K$ versus $r$ strategies could explain in general terms the sequential changes in phytoplankton community structure in coastal waters. Not all communities are this easily explained, of course. One that does not follow the generalities of Margalef et al. (1979) is the occurrence of toxic blooms of the dinoflagellate, Karenia brevis (previously called Gymnodinum breve) on the west coast of Florida (Smayda and Reynolds, 2001). Walsh and Steidinger (2001) have developed a complex hypothesis for the formation of blooms of $K$. brevis which begins with excess phosphate in coastal waters that originates from mine drainage, plus excess iron which is transported from the Sahara during summer on easterly atmospheric waves. A bloom of the nitrogen-fixing bacterium, Trichodesmium, stimulated by the excess $\mathrm{P}$ and $\mathrm{Fe}$, accumulates excess nitrogen, leading to a generalized phytoplankton 


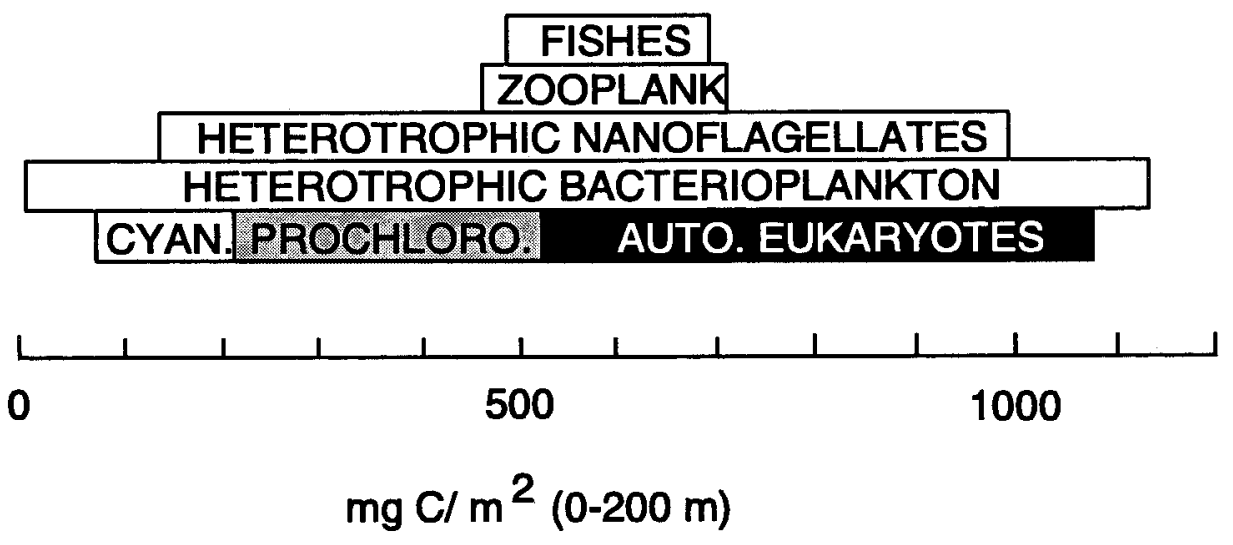

FIG. 1. - Current estimates of biomass in the central North Atlantic gyre. Fishes (from Angel, 1989); zooplankton (from Ashjian et al., 1994, and Ortner et al., 1980); protozoans (from Caron et al., 1995); bacterioplankton, cyanophytes, prochlorophytes, and autotrophic eukaryotes (from Li et al., 1992).

bloom which includes $K$. brevis as a minor component. Selective grazing by zooplankton, a top-down effect, then leads to development of a bloom dominated by toxic $K$. brevis. Historical data since the 1950s tend to support this hypothesis, which is an example of the need to consider multiple factors, both from bottom-up and top-down.

\section{COMPLETING THE FOOD WEB}

Both microbiologists and marine zoologists are guilty of ignoring the interactions between microbial and macro-organismal food webs. In planktonic systems, the interconnections begin with primary production. A significant fraction of marine primary producers are prokaryotes. Because of their small size, prokaryotic primary producers are consumed principally by protozoans or rotifers. When we measure rates of primary production by either uptake of ${ }^{14} \mathrm{C}$ or oxygen evolution, we do not distinguish between prokaryotic picoplankton and larger diatoms. Microbial processes are also frequently underestimated in studies of terrestrial systems, because most of the microbial activity is in soils, the study of which tends to be a separate discipline (Pomeroy, 2001).

\section{Biomass distribution}

Comparisons of the distribution of biomass among groups of organisms were introduced by Elton, and initially were limited to macroorganisms or at most included phytoplankton. Credible estimates of biomass of protozoans, bacteria, and even viruses can now be included. The biomass of microorganisms is significant, indeed becoming dominant in the central gyres of the ocean (Fig. 1). Because metabolic rate and production of biomass increase by about 1.75 per order of magnitude decrease in body size (Banse and Mosher, 1980), the dominance of microorganisms in consumption and production is even greater than that of their biomass (Pomeroy, 2001). It is important to note that microbial dominance of community metabolic processes is the natural condition, and there is no reason to believe that current microbial dominance is the recent result of some of the anthropogenic changes in communities discussed above. There seems little reason to believe that, on a planetary or ecosystem scale, the biomass of bacteria has changed as a result of human activities, either by the cropping of large animals or by eutrophication. The largest known populations of bacteria are in the lithosphere and the ocean (Whitman et al., 1998), where they are little impacted by anthropogenic changes.

\section{Assimilating the macro- and microorganisms}

When one compares the production of bacteria with that of phytoplankton in the ocean (Ducklow, 2000), bacteria would appear to make a relatively small demand on primary production. However, when a typical growth efficiency of 0.2 (del Giorgio and Cole, 2000) is factored in, it is clear that bacteria consume, directly or indirectly, most of the primary production and not just dissolved organic matter released by phytoplankton. The data of Donali et al. (1999) for the Gulf of Riga show this bacterial impact (Fig. 2). Therefore, models of the flux of carbon or energy in the sea will not be realistic if they include only phytoplankton production and the con- 

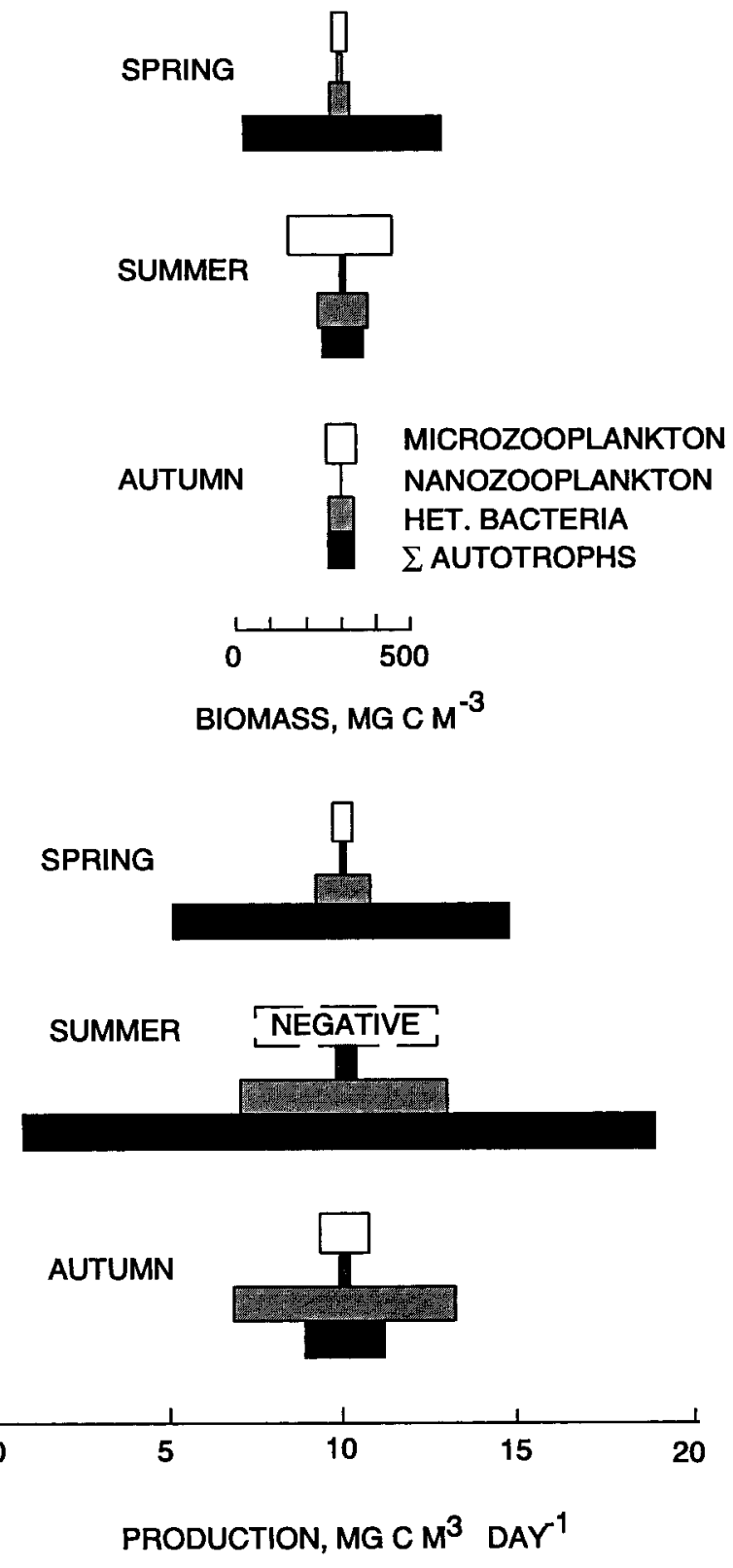

Fig. 2. - Biomass and production of the plankton in the Gulf of Riga from the data of Donali et al. (1999), illustrating the magnitude of microbial production. These data do not include respiratory carbon demand (see text).

sumption of zooplankton and fishes. Probably a majority of mass-balance models of food webs do not include a microbial loop but only a "detritus" state variable, which is usually placed on trophic level 1 with primary production (Cohen et al., 1990; Jarre-Teichmann, 1998). As Figure 3 suggests, this is not a realistic representation of what is happening in the community. Rather than being a primary food source, detritus and dissolved organic matter are links between the eukaryotic food web and the microbial food web. In most planktonic communi- ties, the combined carbon flux from prokaryotic consumers, particulate organic matter and dissolved organic matter through the microbial food web exceeds carbon flow through macroorganisms. The relative growth rates and respiratory rates of the microorganisms and invertebrates show that more non-living organic matter in its various forms is consumed by microorganisms than by eukaryotic detritus feeders.

If microorganisms remove so much organic production from the system before it reaches the fishes, why should modelers of fish populations consider microbial processes in their models? They should, because connectivity can be significant. Painting et al., (1993) and Carr (1998) have shown that the microbial food web is an important link to high trophic levels even in upwelling systems, where significant prokaryotic primary production occurs and protozoans are a significant food source for zooplankton. In central gyres, the microbial loop is virtually the only source of primary and secondary production and must be assumed to be significant for high trophic levels, albeit with a relatively low assimilation efficiency. Moreover, models that assume no loss of primary production to detritus and the microbial loop, do not realistically represent the flux of carbon in the sea and may be overestimating the organic carbon available to high trophic levels.

\section{BRIDGING THE BARRIERS}

One of the barriers to the integration of our understanding of the food web from its various parts is an ever-growing need for specialization as ecology becomes more complex. What was once a single field has become divided into many invisible colleges whose members do not necessarily communicate regularly through meetings and journals in common. As a result, each of us has only a part of the total food web within our purview. In discussing this problem, Brown (2001) compares ecologists to traditional healers in medicine, for whom he uses the Zimbabwean word, ngonga. Brown says that ngonga are less effective in helping the sick than is modern medicine, because they have a less perfect worldview. No worldview is perfect, but modern medicine has the better one. Brown then says that he is an ngonga ecologist, and the implication is that all of us are. Each of us has a limited worldview, one that could be improved by better awareness of what others have learned. Rising out of ngonga ecology 


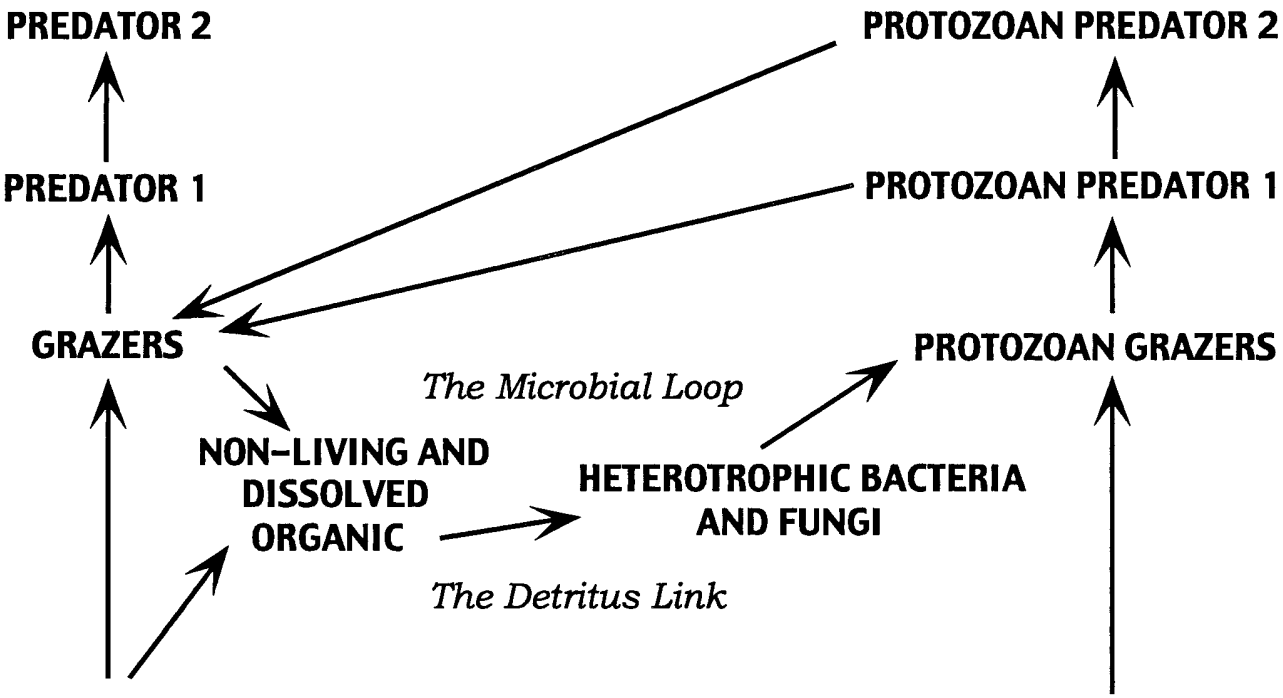

\section{EUKARYOTE PRIMARY PRODUCERS}

\section{PROKARYOTE PRIMARY PRODUCERS}

Fig. 3. - Metazoan and microbial elements of planktonic marine food webs and some of the major connections and interactions.

will require a continuing, conscious effort of building intellectual and political bridges, something that has been advocated many times before (e. g. Holling, 1978; Gunderson et al., 1995; Polis, 1999) but has not yet been fully achieved.

\section{REFERENCES}

Angel, M.V.- 1989. Vertical profiles of pelagic communities in the vicinity of the Azores front and their implications to deep ocean biology. Prog. Oceanogr., 22: 1-46.

Ashjian, C.J., S.L. Smith, C.N. Flagg, A.J. Mariano, W.J. Beherens and P.V.Z. Lane - 1994. The influence of a Gulf Stream meander on the distribution of zooplankton biomass in the slope water, the Gulf Stream, and the Sargasso Sea, described using a shipboard acoustic doppler current profiler. Deep-Sea Res. I, 41: 23-50.

Banse, K. and S. Mosher - 1980. Adult body mass and annual production/biomass relationships of field populations. Ecol. Monogr., 50: 55-379.

Bjørnstad, O.N. and B.T. Grenfell - 2001. Noisy clockwork: Time series analysis of population fluctuations in animals. Science, 293: 638-643.

Boynton, W.R., J.H. Garber, R. Summers and W.H. Kemp - 1995. Inputs, transformations, and transport of nitrogen and phosphorus in Chesapeake Bay and selected tributaries. Estuaries, 18: 285-314.

Brown, J.S. - 2001. Ngongas and ecology: on having a worldview. Oikos 94: 6-16.

Caron, D.A., H.G. Dam, P. Kremer, E.J. Lessard, L.P. Madin, T.C. Malone, J.M. Napp and E.R. Peele - 1995. The contribution of microorganisms to particulate carbon and nitrogen in surface waters of the Sargasso Sea near Bermuda. Deep-Sea Res. I, 42: 943-972.

Carr, M.-E. - 1998. A numerical study of the effect of periodic nutrient supply on pathways of carbon in a coastal upwelling regime. J. Plank. Res., 20: 491-516.

Chin-Leo, G. and R. Benner - 1992. Enhanced bacterioplankton production and respiration at intermediate salinities in the Mississippi River plume. Mar. Ecol. Prog. Ser., 87: 87-103.

Cohen, J.E., F. Briand and C.M. Newman - 1990. Community Food Webs. Data and Theory. Springer, Berlin.

del Giorgio, P.A. and J.J. Cole - 2000. Bacterial energetics and growth efficiency. In: D. L. Kirchman (ed), Microbial Ecology of the Oceans, pp. 289-325. Wiley-Liss, New York.

Donali, E.K., K. Olli, A.-S. Heiskanen and T. Andersen - 1999. Carbon flow patterns in the planktonic food web of the Gulf of Riga, the Baltic Sea: a reconstruction by inverse method. $J$. Mar. Syst., 23: 251-268.

Ducklow, H. W.- 2000. Bacterial production and biomass in the oceans. In: Kirchman, D. L. (ed), Microbial Ecology of the Oceans, pp. 85-120. Wiley-Liss, New York.

Fromentin, J.-M., N.C. Stenseth, J. Gjøsæter and B. Planque - 1998. Long-term fluctuations in cod and pollack along the Norwegian Skagerrak coast. Mar. Ecol. Prog. Ser., 162: 265-278.

Gunderson, L., C.S. Holling and S. Light (eds.) - 1995. Barriers and Bridges to Renewal of Ecosystems and Institutions. Columbia University Press, New York.

Hall, J.A. and K. Safi, 2001 - The impact of in situ fertilization on the microbial food web in the southern Ocean. Deep-Sea Res. II, 48: 2591-2613.

Hare, S.R., N.J. Mantura and R.C. Francis, 1999 - Inverse production regimes: Alaska and West Coast Pacific salmon. Fisheries, 24: 6-14.

Holling, C.S. - 1978. Adaptive Environmental Assessment and Management. John Wiley and Sons, New York.

Hutchings, J.A. - 1996. Spatial and temporal variation in the density of northern cod and a review of hypotheses for the stock's collapse. Canad. J. Fish. Aquat. Sci., 53: 943-962.

Jackson, J.B.C, M.X. Kirby, W.H. Berger, K.A. Bjorndal, L.W Botsford, B.J. Bourgue, R.H. Bradbury, R. Cooke, J. Erlandson, J.A. Estes, T.P. Hughers, S. Kidwell, C. B. Lange, H.S. Lenihan, J.M. Pandofi, C.H. Peterson, R.S. Steneck, M.J. Tegner and R.R. Warner - 2001. Historical overfishing and the recent collapse of coastal ecosystems. Science, 293: 629-638.

Jacobson, L.D., J., A.A. De Oliveira, M. Barange, M.A. CisnerosMata, R. Felix-Uraga, J.R. Hunter, J.Y. Kim, Y. Matsura, M. Niquen, C. Porteiro, B. Rothschild, R.P. Sanchez, R. Serra, A. Uriarte and T. Wada - 2001. Surplus production, variability, and climate change in the great sardine and anchovy fisheries. Can. J. Fish. Aquat. Sci., 58: 1891-1903. 
Jarre-Teichmann, A. - 1998. The potential role of mass balance models for the management of upwelling ecosystems. Ecol. Applic., 8: S93-S103.

Jonas, R. B. - 1997. Bacteria, dissolved organics, and oxygen consumption in salinity stratified Chesapeake Bay, an anoxia paradigm. Amer. Zool. 37: 612-620.

Kendall, R. F. - 1999. Searching for the center. Fisheries 24: 4.

Kornilovs, G., B. R. Sidrevics and J. W. Fippner - 2001. Fish and zooplankton in the central Baltic Sea. ICES J. Mar. Sci. 58: 579-588.

Li, W.K.W., P.M. Dickie, B.D. Irwin and A.M. Wood - 1992. Biomass of bacteria, cyanobacteria, prochlorophytes and photosynthetic eukaryotes in the Sargasso Sea. Deep-Sea Res., 39: $501-519$.

Lotze, H.K., B. Worm and U. Summer - 2001. Strong bottom-up and top-down control of early life stages of macroalgae. Limnol. Oceanogr., 46: 749-757.

Margalef, R., M. Estrada and D. Blasco - 1979. Functional morphology of organisms involved in red tides, as adapted to decaying turbulence. In: D. Taylor and H. Seliger (eds.), Toxic Dinoflagellate Blooms, pp. 89-94. Amsterdam, Elsevier.

Meyers, R.A., J.A. Hutchings and N.J. Barrowman - 1996. Hypotheses for the decline of cod in the North Atlantic. Mar. Ecol. Prog. Ser., 138: 293-308.

Meyers, R.A., B.R. MacKenzie, K.G. Bowers and N.J. Barrowman - 2001. What is the carrying capacity for fish in the ocean? A meta-analysis of population dynamics of North Atlantic cod. Canad. J. Fish. Aquat. Sci. 58: 464-1476.

Nagata, T. - 2000. Production mechanisms of dissolved organic matter. In: D.L. Kirchman (ed.), Microbial Ecology of the Oceans, pp. 121-152. Wiley-Liss, New York.

Nixon, S. W. - 1995. Coastal marine eutrophication: A definition, social causes, and future concerns. Ophelia 41: 199-219.

Ohman, M.D. and H.-J. Hirche - 2001. Density-dependent mortality in an oceanic copepod population. Nature, 412: 638-641.

Ortner, P.B., P.H. Wiebe and J.L. Cox. - 1980. Relationships between oceanic epizooplankton distributions and the seasonal deep chlorophyll maximum in the Northwestern Atlantic ocean. J. Mar. Res. 38: 507-531.

Paine, R.T. - 1980. Food webs: linkage, interaction strength and community infrastructure. J. Anim. Ecol., 49: 667-685.

Painting, S. J., C. L. Moloney and M. I. Lucas - 1993. Simulation and field-measurements of phytoplankton-bacteria-zooplankton interactions in the southern Benguela upwelling region.
Mar. Ecol. Prog. Ser., 100: 55-69.

Polis, G.A. - 1999. Why are parts of the world green? Multiple factors control productivity and the distribution of biomass. Oikos, 86: 3-15.

Pomeroy, L.R. - 2001. Caught in the food web: complexity made simple? Sci. Mar. 65: 31-40.

Pomeroy, L.R., J.E. Sheldon, W.M. Sheldon, Jr., J.O. Blanton, J. Amft and F. Peters - 2000. Seasonal changes in microbial processes in estuarine and continental shelf waters of the southeastern U.S.A. Estuar. Coast. Shelf Sci., 51: 415-428.

Royer, T.C., C.E. Grosch and L.A. Mysak - 2001. Interdecadal variability of Northeast Pacific coastal freshwater and its implications on biological productivity. Prog. Oceanogr., 49: 95-111.

Sampou, P.W. and M. Kemp - 1994. Factors regulating plankton community respiration in Chesapeake Bay. Mar. Ecol. Prog. Ser. 110: 249-258.

Schwartslose, R.A., J. Alheit, A. Bakun, T.R. Baumgartner, R. Cloete, R.J.M. Crawford, W.J. Fletcher, Y. Green-Ruiz, E. Hagen, T. Kawasaki, D. Lluch-Belda, S.E. Lluch-Cota, A. D.MacCall, Y. Matsuura, M.O. Neverez-Martinez, R.H. Parrish, C. Roy, R. Serra, R. Sbust, M. N. Word and J. Z. Zuzunga - 1999. Worldwide large-scale fluctuations of sardine and anchovy populations. S. Afr. J.Mar. Sci., 21: 289-347.

Sherman, K. and A.M. Duda - 1999. Large marine ecosystems: An emerging paradigm for fishery sustainability. Fisheries 24: 5-26.

Smayda, T.J. and C.S. Reynolds - 2001. Community assembly in marine phytoplankton: application of recent models to harmful dinoflagellate blooms. J. Plankt. Res., 23: 447-461.

Turner, R.E. and N.N. Rabalais - 1994. Coastal eutrophication near the Mississippi River delta. Nature, 368: 619-621.

Tyson, R.V. and T.H. Pearson - 1991. Modern and ancient continental shelf anoxia: an overview. In: R.V. Tyson and T.H. Pearson (eds.), Modern and Ancient Continental Shelf Anoxia, pp. 1-24. The Geological Society, Bath.

Verity, P.G. - 1998. Why is relating plankton community structure to pelagic production so problematic? S. Afr. J. Mar. Sci., 19: 333-338.

Walsh, J.J. and K.A. Steidinger - 2001. Saharan dust and Florida red tides: The cyanophyte connection. J. Geophys. Res.Oceans, 106: 11,597-511,612

Whitman, W.B., D.C. Coleman and W.J. Wiebe - 1998. Prokaryotes: The unseen majority. Proc. Natl. Acad. Sci. U.S., 95: $6578-6583$ 